\title{
Dietary patterns and their associations with home food availability among Finnish pre-school children: a cross- sectional study
}

\author{
Henna Vepsäläinen ${ }^{1, *}$, Liisa Korkalo, Vera Mikkilä ${ }^{1}$, Reetta Lehto ${ }^{1,2}$, Carola Ray ${ }^{2}$, \\ Kaija Nissinen ${ }^{1,3}$, Essi Skaffari ${ }^{1}$, Mikael Fogelholm ${ }^{1}$, Leena Koivusilta ${ }^{4}$, Eva Roos ${ }^{2,5}$ and \\ Maijaliisa Erkkola ${ }^{1}$ on behalf of the DAGIS Consortium Group \\ 'Department of Food and Environmental Sciences, University of Helsinki, PO Box 66, Fl-0001 4 University of Helsinki, \\ Helsinki, Finland: ${ }^{2}$ Folkhälsan Research Center, Helsinki, Finland: ${ }^{3}$ Seinäjoki University of Applied Sciences, \\ Seinäjoki, Finland: ${ }^{4}$ School of Health Sciences, University of Tampere, University Consortium of Seinäjoki, Seinäjoki, \\ Finland: ${ }^{5}$ Department of Public Health, Clinicum, University of Helsinki, Helsinki, Finland
}

Submitted 27 April 2017: Final revision received 27 October 2017: Accepted 27 November 2017: First published online 14 January 2018

\begin{abstract}
Objective: To study the associations between home food availability and dietary patterns among pre-school children.

Design: Cross-sectional study in which parents of the participating children filled in an FFQ and reported how often they had certain foods in their homes. We derived dietary pattern scores using principal component analysis, and composite scores describing the availability of fruits and vegetables as well as sugar-enriched foods in the home were created for each participant. We used multilevel models to investigate the associations between availability and dietary pattern scores.

Setting: The DAGIS study, Finland.

Subjects: The participants were 864 Finnish 3-6-year-old children recruited from sixty-six pre-schools. The analyses included 711 children with sufficient data.

Results: We identified three dietary patterns explaining $16.7 \%$ of the variance. The patterns were named 'sweets-and-treats' (high loadings of e.g. sweet biscuits, chocolate, ice cream), 'health-conscious' (high loadings of e.g. nuts, natural yoghurt, berries) and 'vegetables-and-processed meats' (high loadings of e.g. vegetables, cold cuts, fruit). In multivariate models, the availability of fruits and vegetables was inversely associated with the sweets-and-treats pattern $(\beta=-0.05$, $P<0.01)$ and positively associated with the health-conscious $(\beta=0.07, P<0.01)$ and vegetables-and-processed meats patterns $(\beta=0 \cdot 06, P<0 \cdot 01)$. The availability of sugar-enriched foods was positively associated with the sweets-and-treats pattern $(\beta=0 \cdot 10, P<0 \cdot 01)$ and inversely associated with the health-conscious pattern $(\beta=-0 \cdot 03, P<0 \cdot 01)$.

Conclusions: Considering dietary patterns, the availability of sugar-enriched foods in the home seems to have a stronger role than that of fruits and vegetables. Parents should restrict the availability of unhealthy foods in the home.
\end{abstract}

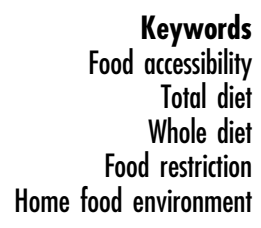

Both among the general population and among children, increasingly common issues worldwide are overweight, obesity and obesity-related health outcomes ${ }^{(1,2)}$. Obesityrelated outcomes are affected by several individual-level characteristics such as genes ${ }^{(3)}$, motivation for healthy eating and exercise ${ }^{(4)}$, as well as knowledge about healthy lifestyles ${ }^{(5)}$. However, individual features are not the only factors related to health behaviours: according to the socio-ecological model, social and physical environmental factors, such as family members, peers, pre-schools, neighbourhoods and food marketing, also play a significant role ${ }^{(6)}$. Food environments, as part of the physical environment, are especially important regarding food intake.

A food environment involves any opportunity to obtain food $^{(7)}$. Food advertising and marketing are parts of a food environment, but also included are the availability and accessibility of foods ${ }^{(8)}$. Multiple studies have examined the associations between food availability and health behaviours. For example, the availability of fruits and 
vegetables in the home has been associated with higher fruit and vegetable intake among children of different ages $^{(9-13)}$. The availability of unhealthy foods at home, however, seems to be negatively linked with fruit and vegetable consumption ${ }^{(14)}$. The availability of unhealthy foods in the home has been connected to savoury snack consumption among 12-13-year-olds ${ }^{(15)}$. Additionally, the availability of chips and sweets in the home was positively associated with a fats and sweets index score in a study of 5-11-year-olds ${ }^{(16)}$.

The majority of studies have looked at the associations between home food availability and single foods or food groups $^{(9-15)}$. However, using dietary patterns as a measure of a person's total diet in epidemiological studies has become more popular in recent years ${ }^{(17)}$. The use of dietary patterns is beneficial, as single nutrients can be correlated and confounded with each other, and, in addition, the combined effect of a total diet may be stronger than the separate effects of the individual foods and nutrients present in the diet ${ }^{(18)}$. Nevertheless, there are only a few studies examining associations between total diets and home food availability among children. Studies in the USA have linked home food availability to the Healthy Eating Index (HEI) among 10-yearolds ${ }^{(19)}$ and to the Dietary Approaches to Stop Hypertension pattern score (DASH score) among 6-11-year-olds. However, a negative association was detected between the availability of unhealthy foods and the DASH score ${ }^{(20)}$. A Puerto Rican study found no association between the availability of healthy or unhealthy foods and HEI among 12-year-olds ${ }^{(21)}$.

Previously, we found an association between home food availability and unhealthy, as well as healthy, dietary patterns among a multinational sample of 10 -year-olds ${ }^{(22)}$. However, since pre-school children are, compared with 10-year-olds, more dependent on their parents' food choices, studies examining associations between the home food availability and dietary patterns among 3-6-year-olds are needed. To our knowledge, only one study has investigated these associations: a study from the USA found that children with limited access to unhealthy foods had a lower 'junk' food intake score and a higher healthy food intake score ${ }^{(23)}$. In the present study, we had two objectives: (i) to identify dietary patterns among Finnish pre-school children based on food consumption outside pre-school; and (ii) to study the associations between home food availability and dietary patterns. Our study adds to the existing literature by addressing these questions among pre-school children whose food choices are more dependent on their parents.

\section{Methods}

\section{Study design, setting and participants}

The present analyses are part of the DAGIS study ${ }^{(24)}$. In the current paper, we report data from the cross-sectional survey conducted in 2015-2016. In 2015, 169 pre-schools in five municipalities in Southern Finland and three municipalities in Western Finland were invited to participate in the study. The invited pre-schools were randomly selected from all municipal pre-schools and private pre-schools from whom the municipalities purchased education services. The randomization was conducted separately for each of the participating municipalities. Of these pre-schools, sixty-seven ( $40 \%)$ did not wish to participate and sixteen (9\%) were excluded due to being a $24 \mathrm{~h}$ pre-school, operating in a language other than Finnish or Swedish, or not having reduced fees for lowincome families. From the eighty-six $(51 \%$ of those invited) pre-schools that gave consent, we invited 3592 children and their families, of whom $983(27 \%)$ consented. Children in pre-schools with a low participation rate ( $\leq 30 \%$ in each of the groups for 3-6-year-olds) were further excluded (ninety-one children in twenty preschools). The data were collected between September 2015 and April 2016 in sixty-six pre-schools. We received no data from twenty-eight consented children. A total of 864 children aged 3-6 years and their parents or legal guardians participated in the study. The participation rate in the pre-schools under study was $29 \%$.

\section{Measurements and variables}

\section{Home food availability}

The questionnaire used to measure the availability of foods was based on a previously published tool ${ }^{(20)}$ and modified by adding foods and/or drinks considered significant and removing items considered unnecessary to better fit the particular study. The parents or legal guardians of the participating children reported how often (never, rarely, sometimes, often, always) they had specified foods in their homes. The food items included in the questionnaire were: fresh vegetables; fresh fruits or berries; frozen vegetables; frozen fruits or berries; sweets or chocolate; sweet cookies; sweet pastries; cereals or muesli with added sugar; yoghurts with added sugar; other dairy products or similar with added sugar (i.e. puddings or quarks); ice cream; soft drinks with added sugar; juices with added sugar; $100 \%$ fruit juices; and cocoa (drink or cocoa powder with added sugar). A composite score describing the availability of fruits and vegetables was created using the frequencies of the availability of certain foods in the home (for more details, see Table 1). Similarly, a score describing the availability of sugar-enriched foods was created. All variables used in the present analyses are described in more detail in Table 1.

\section{Dietary pattern scores}

Food consumption was measured using a forty-seven-item FFQ developed for the DAGIS study. The parents or legal guardians of the participating children were asked to report how many times during the past week the child had consumed different foods at home or in places other than 
Table 1 Variables used in the analyses

\begin{tabular}{|c|c|c|c|c|c|}
\hline $\begin{array}{l}\text { Role in the } \\
\text { analyses }\end{array}$ & Variable name & Survey question & Original answer options & Variable used in analyses & $\begin{array}{l}\text { Type of the } \\
\text { variable used in } \\
\text { analyses }\end{array}$ \\
\hline $\begin{array}{l}\text { Confounding } \\
\text { factor }\end{array}$ & $\begin{array}{l}\text { Parental } \\
\text { education }\end{array}$ & $\begin{array}{l}\text { What is the highest degree of education you/your } \\
\text { partner have/has achieved? }\end{array}$ & $\begin{array}{l}\text { Comprehensive school; vocational school; } \\
\text { secondary school; polytechnic degree; } \\
\text { master's degree; licentiate/doctoral } \\
\text { degree; other }\end{array}$ & $\begin{array}{l}\text { Highest education in the family in three } \\
\text { classes: secondary school or lower; } \\
\text { polytechnic degree; master's degree or } \\
\text { higher }\end{array}$ & Classified \\
\hline \multirow[t]{2}{*}{$\begin{array}{l}\text { Exposure: } \\
\text { home food } \\
\text { availability }\end{array}$} & $\begin{array}{l}\text { Fruits and } \\
\text { vegetables } \\
\text { availability } \\
\text { score }\end{array}$ & $\begin{array}{l}\text { How often are there (i) fresh vegetables, (ii) fresh } \\
\text { fruits or berries, (iii) frozen vegetables, (iv) frozen } \\
\text { fruits or berries and (v) } 100 \% \text { fruit juices in the } \\
\text { home? }\end{array}$ & Never; rarely; sometimes; often; always & $\begin{array}{l}\text { Sum variable: never }=1 \text {, rarely }=2 \text {, etc.; } \\
\text { range 5-25; Cronbach's } a=0.62\end{array}$ & $\begin{array}{l}\text { Continuous } \\
\text { (tables), } \\
\text { classified into } \\
\text { quarters } \\
\text { (figures) }\end{array}$ \\
\hline & $\begin{array}{l}\text { Sugar-enriched } \\
\text { foods } \\
\text { availability } \\
\text { score }\end{array}$ & $\begin{array}{l}\text { How often are there (i) sweets/chocolate, (ii) sweet } \\
\text { cookies, (iii) sweet pastries, (iv) ice cream, (v) soft } \\
\text { drinks and (vi) juices with added sugar in the } \\
\text { home? }\end{array}$ & Never; rarely; sometimes; often; always & $\begin{array}{l}\text { Sum variable, never }=1 \text {, rarely }=2 \text {, etc.; } \\
\text { range } 6-30 ; \text { Cronbach's } a=0.72\end{array}$ & $\begin{array}{l}\text { Continuous } \\
\text { (tables), } \\
\text { classified into } \\
\text { quarters } \\
\text { (figures) }\end{array}$ \\
\hline \multirow{3}{*}{$\begin{array}{l}\text { Outcomes: } \\
\text { dietary } \\
\text { pattern } \\
\text { scores }\end{array}$} & $\begin{array}{l}\text { Sweets-and- } \\
\text { treats pattern } \\
\text { score }\end{array}$ & $\begin{array}{l}\text { How often during the past week has your child eaten } \\
\text { the following foods? Altogether } 47 \text { food items }\end{array}$ & $\begin{array}{l}\text { Numeric answer separately for each food } \\
\text { item }\end{array}$ & $\begin{array}{l}\text { Principal components analysis; } \\
\text { standardized pattern scores; mean } \\
0.00 \text { (sD } 1.00 \text { ), range }-2.47 \text { to } 5.37\end{array}$ & Continuous \\
\hline & $\begin{array}{l}\text { Health- } \\
\text { conscious } \\
\text { pattern score }\end{array}$ & $\begin{array}{l}\text { How often during the past week has your child eaten } \\
\text { the following foods? Altogether } 47 \text { food items }\end{array}$ & $\begin{array}{l}\text { Numeric answer separately for each food } \\
\text { item }\end{array}$ & $\begin{array}{l}\text { Principal components analysis; } \\
\text { standardized pattern scores; mean } \\
0.00 \text { (SD } 1.00 \text { ), range }-2.24 \text { to } 10.02\end{array}$ & Continuous \\
\hline & $\begin{array}{l}\text { Vegetables- } \\
\text { and- } \\
\text { processed } \\
\text { meats } \\
\text { pattern score }\end{array}$ & $\begin{array}{l}\text { How often during the past week has your child eaten } \\
\text { the following foods? Altogether } 47 \text { food items }\end{array}$ & $\begin{array}{l}\text { Numeric answer separately for each food } \\
\text { item }\end{array}$ & $\begin{array}{l}\text { Principal components analysis; } \\
\text { standardized pattern scores; mean } \\
0.00 \text { (sD } 1.00 \text { ), range }-2.45 \text { to } 4.76\end{array}$ & Continuous \\
\hline
\end{tabular}


at pre-school. The FFQ included three answer columns: 'not at all', 'times per week' and 'times per day'. The instruction was to either tick the 'not at all' box or to write a number in one of the other columns. We intentionally restricted the FFQ to not cover municipality-provided foods and drinks consumed during the pre-school hours. Dietary pattern scores based on the FFQ food groups were created for each participant (see 'Statistical methods' and Table 1 for more detail).

\section{Confounding variables}

The parents or legal guardians reported their educational level (for both parents or legal guardians, if applicable). In the analyses, we used the highest education in the family as a proxy for a family's educational level (Table 1). In additional analyses, we used relative household income (parent-reported gross household income weighted with the number of household members) as a confounder (data not shown).

\section{Statistical methods}

\section{Dietary patterns}

To identify existing dietary patterns in the sample, principal component analysis was conducted (using the statistical software package IBM SPSS Statistics version 22). Consumption frequencies (times per week) of the FFQ food items were used as input variables. Only children with complete FFQ ( $n 756,88 \%$ of the participants) were included in the principal component analysis. Based on the eigenvalue (minimum value of at least 1.5 ), scree plot and the interpretability of the components, three components with the highest eigenvalues were chosen. The analysis was then rerun with a forced three-component solution and rotated with an orthogonal Varimax transformation to enhance the interpretation. Standardized principal component scores for these three components, i.e. data-driven dietary patterns, were calculated for each participant by assigning weights to their frequency of use of each food. The obtained dietary pattern scores thus represented how closely the food consumption of each participant reflected each of the empirically derived dietary patterns (a higher score indicating a stronger adherence to a dietary pattern). Factorability of the data was supported by Bartlett's test of sphericity $\left(\chi^{2}=4230 \cdot 169\right.$, $\mathrm{df}=1081, P<0 \cdot 001)$ and the Kaiser-Meyer-Olkin value of 0.618 indicated sampling adequacy.

\section{Associations between home food availability and dietary patterns}

We examined the associations between the availability scores and the dietary pattern scores using multilevel linear mixed models (using the statistical software package SAS version 9.4; PROC MIXED). We treated pre-school as the highest level in the models, to take the clustering of the participants due to the pre-school-based sampling strategy into account. The family level was used as the middle level, because the proportion of children living in the same household was relatively high (the sample involved ninety-seven families with two or three participating children). Individual participants were treated as the lowest level of the three-level model. Since we assumed the data to be nested, i.e. each level to be a subset of the other, we excluded one child from a family whose two children attended different pre-schools. Pre-schools and families nested within them were considered to have fixed effects. We used the Kenward and Roger approximation to calculate the denominator degrees of freedom for statistical tests pertaining to fixed effects ${ }^{(25)}$. An unconditional model with no predictors was used to estimate the amount of variance in dietary pattern scores attributable to participating children, their families and pre-schools (intraclass correlation coefficient). Associations between the availability scores and the dietary pattern scores were assessed using multilevel models, with each of the availability scores used separately as predictors (models 1 and 2). In addition, multivariable models were used to identify the possible independent roles of the two different availability scores (model 3). To improve model fit indices, we adjusted models 1-3 for the highest education in the family. In additional analyses, the models were adjusted for relative household income (data not shown). Unadjusted models are presented in the online supplementary material, Supplemental Table 1. Differences between groups were illustrated by calculating the least-square means of the dietary pattern scores in different combinations of the fruits and vegetable and sugar-enriched food availability score quarters (adjusted for the highest education in the family). Interactions between the availability score categories were tested using Wald's $Z$ test.

\section{Results}

\section{Dietary patterns}

The three components chosen explained $16.7 \%$ of the variance in total and their eigenvalues were $>1.5$. The factor loadings of the rotated Varimax solution with absolute values of 0.3 or more, eigenvalues and the proportion of total variance explained are shown in Table 2 . The first component was labelled 'sweets-and-treats pattern' based on its high loadings of e.g. sweet biscuits and cereal bars; chocolate; ice cream; sweets; and soft drinks. The second component was characterized by high loadings of e.g. nuts; natural yoghurt; berries; egg; and wholegrain porridge, non-sweetened breakfast cereals and muesli, and was thus named 'health-conscious pattern'. Finally, we named the third component 'vegetablesand-processed meats pattern' based on the high loadings of e.g. fresh vegetables; cold cuts; fresh fruit; flavoured yoghurt; and wholemeal bread. The dietary pattern scores did not differ between genders. 
Table 2 Characteristics of the three dietary patterns found in Finnish pre-school children aged 3-6 years, DAGIS study, September 2015-April 2016

\begin{tabular}{|c|c|c|c|}
\hline & $\begin{array}{l}\text { Pattern 1: } \\
\text { Sweets- } \\
\text { and-treats }\end{array}$ & $\begin{array}{l}\text { Pattern 2: } \\
\text { Health- } \\
\text { conscious }\end{array}$ & $\begin{array}{l}\text { Pattern 3: } \\
\text { Vegetables- } \\
\text { and-processed } \\
\text { meats }\end{array}$ \\
\hline $\begin{array}{l}\text { Sweet biscuits and cereal } \\
\text { bars }\end{array}$ & 0.54 & 0.29 & 0.06 \\
\hline Chocolate & 0.53 & $0 \cdot 17$ & $-0 \cdot 10$ \\
\hline Ice cream & 0.50 & 0.06 & -0.03 \\
\hline Sweets & 0.47 & -0.10 & 0.06 \\
\hline Soft drinks & 0.47 & -0.15 & 0.07 \\
\hline $\begin{array}{l}\text { Sugar-sweetened juice } \\
\text { drinks }\end{array}$ & 0.42 & -0.09 & -0.03 \\
\hline Sweet pastries & 0.38 & 0.18 & 0.03 \\
\hline Crisps and popcorn & 0.37 & -0.11 & 0.13 \\
\hline $\begin{array}{l}\text { Sugar-sweetened } \\
\text { breakfast cereals and } \\
\text { muesli }\end{array}$ & 0.37 & -0.02 & -0.02 \\
\hline $\begin{array}{l}\text { Flavoured nuts, almonds } \\
\text { and seeds }\end{array}$ & 0.35 & 0.26 & -0.17 \\
\hline $\begin{array}{l}\text { Plain nuts, almonds and } \\
\text { seeds }\end{array}$ & -0.11 & 0.59 & 0.04 \\
\hline $\begin{array}{l}\text { Natural yoghurt and } \\
\text { quark }\end{array}$ & -0.11 & 0.52 & $0 \cdot 18$ \\
\hline Berries & -0.17 & 0.47 & 0.30 \\
\hline Egg & 0.14 & 0.44 & 0.15 \\
\hline $\begin{array}{l}\text { Wholegrain porridge, } \\
\text { non-sweetened } \\
\text { breakfast cereals and } \\
\text { muesli }\end{array}$ & -0.18 & 0.43 & -0.08 \\
\hline Dried fruit and berries & 0.06 & 0.41 & -0.10 \\
\hline $\begin{array}{l}\text { Wholegrain rice and } \\
\text { pasta }\end{array}$ & -0.16 & 0.40 & -0.09 \\
\hline $\begin{array}{l}\text { Peas, beans, lentils and } \\
\text { soya }\end{array}$ & -0.06 & 0.33 & 0.04 \\
\hline $\begin{array}{l}\text { Cooked and canned } \\
\text { vegetables }\end{array}$ & -0.04 & 0.32 & 0.30 \\
\hline $\begin{array}{l}\text { Commercial baby foods } \\
\text { and smoothies }\end{array}$ & 0.05 & 0.31 & -0.02 \\
\hline Fresh vegetables & -0.24 & 0.20 & 0.54 \\
\hline Cold cuts & 0.10 & -0.09 & 0.51 \\
\hline Fresh fruit & -0.15 & 0.28 & 0.40 \\
\hline $\begin{array}{l}\text { Flavoured yoghurt and } \\
\text { quark }\end{array}$ & 0.14 & -0.19 & 0.40 \\
\hline Wholemeal bread & 0.01 & -0.02 & 0.39 \\
\hline High-fat cheese & 0.06 & -0.01 & 0.36 \\
\hline Fruit juice & 0.02 & 0.18 & 0.36 \\
\hline $\begin{array}{l}\text { Sausages, frankfurters } \\
\text { and luncheon meats }\end{array}$ & 0.31 & -0.12 & 0.33 \\
\hline Eigenvalue & $3 \cdot 2$ & $2 \cdot 8$ & $1 \cdot 8$ \\
\hline $\begin{array}{l}\% \text { of total variance } \\
\text { explained }\end{array}$ & $6 \cdot 8$ & $6 \cdot 1$ & 3.8 \\
\hline
\end{tabular}

Altogether nineteen foods (skimmed milk; berry, fruit and chocolate porridge; reduced-sugar juices and soft drinks; puddings; white bread; $1 \%$ fat and semi-skimmed milk; flavoured or sweetened milk- or plant-based drinks; lowfat cheese; jams, marmalades and sweetened spreads; added sugar, honey and syrup; fish; berry and fruit fools and thickened soups; rye bread, crispbread and thin rye crackers; whole milk; white rice and pasta; white meat; canned and frozen fruit; potato; red meat) did not load with an absolute value of 0.3 or more to any of the three patterns identified and are not shown in the table. Loadings with an absolute value of 0.3 or more are shown in bold.

\section{Participants}

In the final analyses we included 714 children ( $83 \%$ of the children with any data) with at least one of the two availability scores and educational level data (models 1-2) and 711 children ( $82 \%$ of the children with any data) with complete availability scores and educational level data (model 3). The children were from sixty-six pre-schools, had a mean age of 4.7 (SD 0.89 ) years and $49 \%$ of them were girls. Less than $4 \%$ of the parents reported speaking a language other than Finnish or Swedish (the official languages of Finland) with the participating child, making the sample fairly homogeneous in terms of ethnicity. Furthermore, in only $7 \%$ of the cases did the parents belong to opposite educational level categories (secondary school or lower $v$. master's degree or higher). Table 3 presents the characteristics of the participating children, their families and the availability scores of fruits and vegetables as well as sugar-enriched foods. In addition, Table 3 shows the dietary pattern scores in parental education categories. Children from parents with a higher educational level had lower sweets-and-treats as well as vegetables-and-processed meats pattern scores and higher health-conscious pattern scores compared with children from parents with a lower educational level. Higher educated families had higher fruits and vegetables availability scores compared with families with lower educational level. The children excluded from the current analyses were mostly boys $\left(60 \%, \chi^{2}\right.$ test $\left.P=0.043\right)$ and their parents were less educated compared with the children with complete data $\left(\chi^{2}\right.$ test $\left.P=0 \cdot 001\right)$. In terms of age, availability scores and dietary pattern scores, the excluded children did not differ from the participants included in the analyses.

\section{Home food availability and dietary pattern scores}

Judging by the unconditional model, most of the variance in the dietary pattern scores was attributable to the family level: the intraclass correlation coefficient was 0.93 for sweets-and-treats as well as for health-conscious pattern scores, whereas for the vegetables-and-processed meats pattern score, the intraclass correlation coefficient was $0 \cdot 90$. The variance attributable to the pre-school level was $1.5 \%$ for the sweets-and-treats pattern score, $3.3 \%$ for the health-conscious pattern score and $0 \%$ for the vegetablesand-processed meats pattern score. These percentages remained nearly unchanged when the availability factors were added to the models, as shown in Table 4.

Model 1 (Table 4) shows the associations between the availability of fruits and vegetables and dietary pattern scores, whereas Model 2 shows the associations between the availability of sugar-enriched foods and dietary pattern scores. Both models were adjusted for parental education. Model 3 shows the aforementioned associations with both availability scores simultaneously in the model. The availability of fruits and vegetables was positively associated with the health-conscious pattern score, whereas the availability of sugar-enriched foods was positively associated with the sweets-and-treats pattern score. We also found an inverse association between the fruits and vegetables availability score and the sweets-and-treats pattern score. Similarly, the availability of sugar-enriched 
Table 3 Age of the participating children, home food availability scores and dietary pattern scores, by parental education, among Finnish pre-school children aged 3-6 years, DAGIS study, September 2015-April 2016

\begin{tabular}{|c|c|c|c|c|c|c|c|c|c|}
\hline & \multirow{2}{*}{\multicolumn{2}{|c|}{ All $(n 711)$}} & \multicolumn{6}{|c|}{ Highest education in the family } & \multirow[b]{3}{*}{$P$ value* } \\
\hline & & & \multicolumn{2}{|c|}{$\begin{array}{l}\text { Secondary school } \\
\text { or lower ( } n \text { 148) }\end{array}$} & \multicolumn{2}{|c|}{$\begin{array}{c}\text { Polytechnic } \\
\text { degree (n 302) }\end{array}$} & \multicolumn{2}{|c|}{$\begin{array}{l}\text { Master's degree } \\
\text { or higher ( } n 261)\end{array}$} & \\
\hline & Mean & SD & Mean & SD & Mean & SD & Mean & SD & \\
\hline Age (years) & 4.72 & 0.89 & 4.72 & 0.93 & $4 \cdot 70$ & 0.87 & 4.74 & 0.90 & 0.91 \\
\hline \multicolumn{10}{|l|}{ Home food availability scores } \\
\hline Fruits and vegetables availability score & $20 \cdot 40$ & $2 \cdot 81$ & $19 \cdot 96$ & $2 \cdot 93$ & $20 \cdot 26$ & $2 \cdot 80$ & $20 \cdot 82$ & 2.71 & $<0.01$ \\
\hline $\begin{array}{l}\text { Sugar-enriched foods availability score } \\
\text { Dietary pattern scores } \delta\end{array}$ & $16 \cdot 53$ & 3.59 & $16 \cdot 16$ & 3.57 & $16 \cdot 65$ & 3.63 & $16 \cdot 61$ & $3 \cdot 55$ & 0.37 \\
\hline Sweets-and-treats dietary pattern score & -0.02 & 1.00 & $0 \cdot 16$ & $1 \cdot 10$ & 0.00 & 1.01 & $-0 \cdot 14$ & 0.90 & 0.01 \\
\hline Health-conscious dietary pattern score & -0.02 & 0.94 & $-0 \cdot 16$ & 1.02 & -0.10 & 0.89 & 0.16 & 0.93 & $<0.01$ \\
\hline Vegetables-and-processed meats dietary pattern score & -0.01 & 0.99 & $0 \cdot 19$ & 1.07 & -0.02 & 1.03 & -0.10 & 0.87 & 0.01 \\
\hline
\end{tabular}

*The $P$ value shows the result of ANOVA to compare availability scores and dietary pattern scores between the three parental education levels.

†A composite score describing the availabilities of fresh vegetables, fresh fruits or berries, frozen vegetables, frozen fruits or berries, and $100 \%$ fruit juices in the home, range 5-25.

$\ddagger$ A composite score describing the availabilities of sweets or chocolate, sweet cookies, sweet pastries, ice cream, soft drinks and juices with added sugar in the home, range 6-30.

$\S$ Scores derived for every participant by principal component analysis by assigning weights to each participant's food consumption frequency. Higher pattern score indicates stronger adherence to the dietary pattern in question.

foods was inversely associated with the health-conscious pattern score. In addition, the availability of fruits and vegetables was positively associated with the vegetablesand-processed meats pattern score, whereas the inverse association between the sugar-enriched foods availability score and the vegetables-and-processed meats pattern score was borderline significant. Models adjusted for relative household income yielded similar results (data not shown). Figures 1-3 illustrate dietary pattern scores in quarters of fruits and vegetables and sugar-enriched foods availability scores. Statistically significant interactions between fruits and vegetables and sugar-enriched availability scores were detected for all dietary pattern scores.

\section{Discussion}

\section{Key results}

In this sample of Finnish pre-school children, we identified three dietary patterns named sweets-and-treats, healthconscious and vegetables-and-processed meats. The availability of fruits and vegetables was associated with lower sweets-and-treats pattern scores and higher healthconscious and vegetables-and-processed meats pattern scores. However, the availability of sugar-enriched foods was associated with higher sweets-and-treats and lower health-conscious pattern scores. In addition, considering the sweets-and-treats pattern, the role of the sugarenriched foods was greater than that of the fruits and vegetables. High availability of fruits and vegetables in the home did not seem to protect the children from the effect of the sugar-enriched foods. The unique feature of the present study was the use of dietary patterns as an outcome in a sample of 3-6-year-olds.

\section{Interpretation and generalizability}

Only a few studies have investigated dietary patterns among pre-school children. Since principal component analysis requires multiple subjective decisions, several different results are possible and acceptable, and consistencies are difficult to evaluate. However, quite commonly, two or three dietary patterns are identifiable, and the most frequently emerging patterns among children of pre-school age have been characterized as 'healthy' and 'unhealthy'(26). The fact that we arrived with dietary patterns very similar to these commonly found patterns suggests that the FFQ is an adequate tool to assess dietary behaviour among pre-school children outside pre-school hours. A sample of British 4-year-olds ${ }^{(27)}$ and 5-year-old Brazilian pre-schoolers revealed relatively similar patterns ${ }^{(28)}$. Since the vegetables-and-processed meats pattern consisted of both healthy and unhealthy foods, we had difficulties in naming it. However, we feel that the pattern represents a true situation: a diet with mixed choices, some healthier than others. In fact, a similarly mixed dietary pattern has previously been found among 3-6-year-old French children ${ }^{(29)}$. Other studies have also reported mixed patterns with high intakes of both meat and vegetables ${ }^{(27,28)}$. Despite differences in cultural backgrounds, children may express fairly similar dietary patterns: for example, in a geographically and culturally diverse sample of 10-year-olds we have identified two almost-identical dietary patterns in twelve countries ${ }^{(30)}$.

Home availability or accessibility is one of the determinants most consistently associated with fruit and vegetable consumption among children and adolescents ${ }^{(31)}$. Our study supports the suggestion that the availability of fruits and vegetables in the home promotes healthy dietary patterns. This is consistent with several previous studies, 
Table 4 Associations between home food availability scores and dietary pattern scores, adjusted for highest education in the family, among Finnish pre-school children aged 3-6 years, DAGIS study, September 2015-April 2016

\begin{tabular}{|c|c|c|c|c|c|c|c|c|c|}
\hline & \multicolumn{3}{|c|}{$\begin{array}{l}\text { Model 1: education + fruits } \\
\text { and vegetables availability } \\
\text { score } \\
(n 714)\end{array}$} & \multicolumn{3}{|c|}{$\begin{array}{c}\text { Model 2: education + sugar- } \\
\text { enriched foods availability } \\
\text { score } \\
(n 714)\end{array}$} & \multicolumn{3}{|c|}{$\begin{array}{l}\text { Model 3: education + fruits and } \\
\text { vegetables availability } \\
\text { score + sugar-enriched foods } \\
\text { availability score } \\
(n 711)\end{array}$} \\
\hline & Estimate & SE & $P$ value & Estimate & SE & $P$ value & Estimate & SE & $P$ value \\
\hline \multicolumn{10}{|l|}{ Sweets-and-treats pattern } \\
\hline \multicolumn{10}{|l|}{ Fixed effects } \\
\hline Intercept & 0.33 & 0.30 & 0.28 & $-1 \cdot 14$ & 0.20 & $<0.01$ & -0.45 & 0.30 & 0.13 \\
\hline Education & -0.15 & 0.05 & 0.01 & $-0 \cdot 16$ & 0.05 & $<0.01$ & -0.14 & 0.05 & $<0.01$ \\
\hline Fruits and vegetables availability score* & -0.00 & 0.01 & 0.93 & & & & -0.05 & 0.01 & $<0.01$ \\
\hline $\begin{array}{l}\text { Sugar-enriched foods availability score } \\
\text { ICC (\%) }\end{array}$ & & & & 0.09 & 0.01 & $<0.01$ & 0.10 & 0.01 & $<0.01$ \\
\hline Individual level & $5 \cdot 6$ & & & $6 \cdot 3$ & & & $6 \cdot 4$ & & \\
\hline Family level & 94.4 & & & 93.7 & & & $93 \cdot 6$ & & \\
\hline Pre-school level & 0.0 & & & 0.0 & & & 0.0 & & \\
\hline \multicolumn{10}{|l|}{ Model fit } \\
\hline $\begin{array}{l}\mathrm{AIC} \\
\mathrm{BIC}\end{array}$ & $\begin{array}{l}1849 \cdot 2 \\
1853 \cdot 5\end{array}$ & & & $\begin{array}{l}1777 \cdot 1 \\
1781 \cdot 5\end{array}$ & & & $\begin{array}{l}1767 \cdot 7 \\
1772 \cdot 1\end{array}$ & & \\
\hline \multicolumn{10}{|l|}{ Health-conscious pattern } \\
\hline \multicolumn{10}{|l|}{ Fixed effects } \\
\hline Intercept & -1.52 & 0.28 & $<0.01$ & $-0 \cdot 10$ & 0.20 & 0.64 & $-1 \cdot 23$ & 0.29 & $<0.01$ \\
\hline Education & 0.13 & 0.05 & 0.01 & 0.16 & 0.05 & $<0.01$ & 0.12 & 0.05 & 0.01 \\
\hline Fruits and vegetables availability score* & 0.06 & 0.01 & $<0.01$ & & & & 0.07 & 0.01 & $<0.01$ \\
\hline $\begin{array}{l}\text { Sugar-enriched foods availability score† } \\
\text { ICC }(\%)\end{array}$ & & & & -0.02 & 0.01 & 0.13 & -0.03 & 0.02 & $<0.01$ \\
\hline Individual level & $4 \cdot 6$ & & & 4.5 & & & 4.7 & & \\
\hline Family level & 94.6 & & & 95.5 & & & $95 \cdot 0$ & & \\
\hline Pre-school level & 0.8 & & & 0.0 & & & 0.3 & & \\
\hline \multicolumn{10}{|l|}{ Model fit } \\
\hline $\mathrm{AIC}$ & 1722.4 & & & $1737 \cdot 2$ & & & $1713 \cdot 1$ & & \\
\hline $\mathrm{BIC}$ & 1729 & & & $1741 \cdot 6$ & & & $1719 \cdot 7$ & & \\
\hline \multicolumn{10}{|l|}{ Vegetables-and-processed meats pattern } \\
\hline Intercept & -0.65 & 0.30 & 0.03 & 0.38 & 0.21 & 0.08 & -0.58 & 0.31 & 0.06 \\
\hline Education & $-0 \cdot 17$ & 0.05 & $<0.01$ & $-0 \cdot 14$ & 0.05 & 0.01 & $-0 \cdot 17$ & 0.05 & $<0.01$ \\
\hline Fruits and vegetables availability score ${ }^{*}$ & 0.05 & 0.01 & $<0.01$ & & & & 0.06 & 0.02 & $<0.01$ \\
\hline $\begin{array}{l}\text { Sugar-enriched foods availability score† } \\
\text { ICC (\%) }\end{array}$ & & & & -0.00 & 0.01 & 0.67 & -0.02 & 0.01 & 0.07 \\
\hline Individual level & $10 \cdot 2$ & & & $10 \cdot 0$ & & & $10 \cdot 3$ & & \\
\hline Family level & $89 \cdot 8$ & & & $90 \cdot 0$ & & & 89.7 & & \\
\hline Pre-school level & 0.0 & & & 0.0 & & & 0.0 & & \\
\hline \multicolumn{10}{|l|}{ Model fit } \\
\hline AIC & $1874 \cdot 3$ & & & 1883.7 & & & $1866 \cdot 1$ & & \\
\hline $\mathrm{BIC}$ & $1878 \cdot 7$ & & & 1888 & & & $1870 \cdot 4$ & & \\
\hline
\end{tabular}

ICC, intraclass correlation coefficient; AIC, Akaike information criterion (smaller is better); BIC, Bayesian information criterion (smaller is better).

${ }^{*}$ Composite score consisting of the availability frequencies of fresh vegetables, fresh fruits, frozen vegetables, frozen fruits or berries and $100 \%$ fruit juices in the home.

†Composite score consisting of the availability frequencies of sweets and chocolate, sweet cookies, sweet pastries, ice cream, soft drinks and juices with added sugar in the home.

although only a few studies involved the participation of children of pre-school age ${ }^{(10,23)}$. In our study, having sugar-enriched foods at home seemed to be associated with an unhealthy dietary pattern, even when fruits and vegetables were also present. Previously, we obtained similar results in a large sample of school-aged children $^{(22)}$, who probably have access to foods both inside and outside the home and are generally less dependent on their parents than the pre-school children in the present study. Our study also supports the well-established association between parents' higher education and healthy dietary habits in children ${ }^{(31)}$.
It is obvious that children eat what their parents buy and have in the home; however, factors affecting food purchasing in families are complex. For example, in an Australian interview study, parents of 5-6-year-olds thought that their children's diets were influenced by the foods they had available in the home but, conversely, they tended to offer their children foods based on their children's tastes and preferences ${ }^{(32)}$. Many parents also shop with their children and compared with older children, preschool children may initiate more food requests while in a grocery store ${ }^{(33)}$. Calloway et al. reported that pre-school children initiated on average 5.7 requests per shopping 


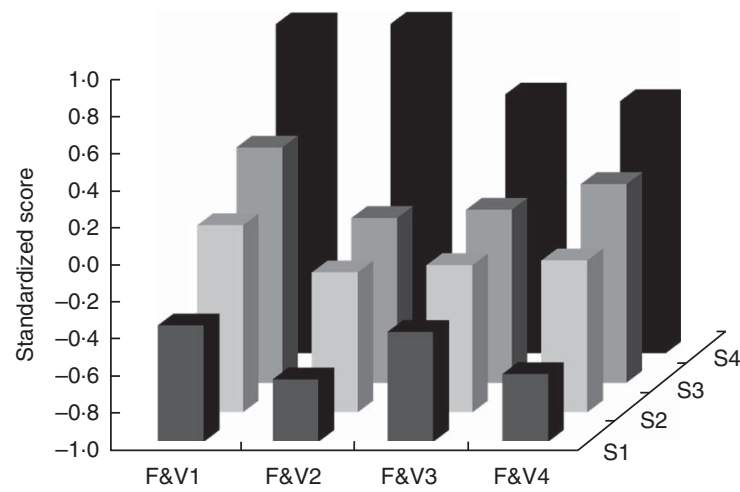

Fig. 1 Sweets-and-treats pattern scores in quarters of fruits and vegetables availability scores (horizontal axis, F\&V1F\&V4) and sugar-enriched foods availability scores (vertical axis, S1-S4) among Finnish pre-school children aged 3-6 years ( $n$ 711), DAGIS study, September 2015-April 2016. Interaction between availability scores was statistically significant $(P<0.0001)$

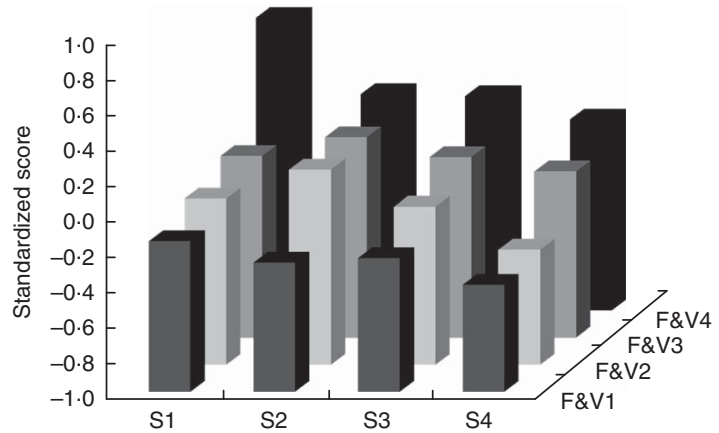

Fig. 2 Health-conscious pattern scores in quarters of sugarenriched foods availability scores (horizontal axis, S1-S4) and fruits and vegetables availability scores (vertical axis, F\&V1F\&V4) among Finnish pre-school children aged 3-6 years ( $n 711)$, DAGIS study, September 2015-April 2016. Interaction between availability scores was statistically significant $(P=0.0185)$

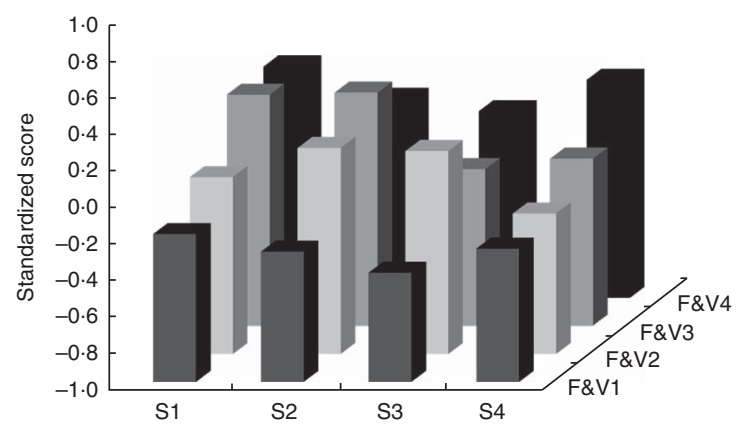

Fig. 3 Vegetables-and-processed meats pattern scores in quarters of sugar-enriched foods availability scores (horizontal axis, S1-S4) and fruits and vegetables availability scores (vertical axis, F\&V1-F\&V4) among Finnish pre-school children aged 3-6 years ( $n$ 711), DAGIS study, September 2015-April 2016. Interaction between availability scores was statistically significant $(P=0.0219)$

trip, of which a little less than one-third were considered healthy ${ }^{(34)}$. In the same study, the parents granted an average of $46 \%$ of these requests. Thus, it can be argued that pre-school children can affect the foods available in the home.

In the present paper, we did not investigate the social food environment. Sociocultural factors (such as role modelling and parental restriction) have proved to be crucial influences. As van der Horst et al. have shown, these factors are even more consistently associated with dietary behaviour than home availability or accessibility $^{(35)}$. It is, however, hard to compare the roles of the physical and social home food environments due to their probable interdependence ${ }^{(36)}$. Regarding the social food environment, previous studies have, for instance, found either no association $^{(10,13,16,20)}$ or an inverse association ${ }^{(11)}$ between restrictive food practices and children's fruit and vegetable intake. Furthermore, it has been stated that restricting access to desired foods ('overt' control which is visible to the child ${ }^{(37)}$ ) may lead to an increase in children's eagerness to consume those foods ${ }^{(38)}$. Thus, it can be concluded that not all restriction techniques are recommendable. Nevertheless, as Rosenkranz and Dzewaltowski noted, by controlling the home food availability ('covert' control which the child cannot detect ${ }^{(37)}$ ), parents have the opportunity to influence the diets of their children without excessively restricting them ${ }^{(39)}$. Our results support this claim as a lack of sugar-enriched foods in the home was associated with healthier diet among pre-school children.

In our sample, only a small amount of variance in dietary pattern scores was attributable to the pre-school level, probably due to the FFQ measuring only foods eaten outside pre-school. However, families living in the same area may have somewhat similar food practices and consumption norms, both influencing children's dietary patterns. In addition, the neighbourhood socio-economic status may be associated with the children's food behaviour. The policies and practices at the pre-schools can also affect children's food intake in the home, justifying the use of multilevel analyses in our study. We intentionally measured only foods eaten outside pre-school hours, since most of the differences in the diets of Finnish preschool children are probably due to foods eaten at home because of the municipally organized pre-school catering. In addition, the parents of the participating children would not have been able to assess the foods the children had eaten at pre-school. The positive impact of a healthy home food environment might also reach beyond the home: research indicates that adolescents who had more fruits available in their homes ate a more balanced school lunch ${ }^{(40)}$. In addition, a healthy home food environment might also be associated with a lower BMI through its positive effects on a child's diet ${ }^{(41)}$. Thus, future interventions and health promotion campaigns should emphasize the home food environment as a factor associated with healthy eating and health in general. In addition, these health promotion campaigns should offer parents the means to cope with food requests initiated by 
children while shopping with them and emphasize the importance of limiting the availability of unhealthy foods in the home.

\section{Limitations}

To our knowledge, no culturally appropriate FFQ with more detailed measurement of fruit and vegetable as well as sugar-enriched food intakes among 3-6-year-olds were available. Thus, we used a non-validated FFQ to measure food behaviour. However, since we used dietary pattern scores instead of single foods or food groups as outcomes, the effect of the possible misreporting is not likely to be substantial. Nevertheless, it is possible that misreporting, especially under-reporting, can attenuate possible associations between the exposure and the outcome, even though the dietary patterns themselves are not significantly altered by misreporting ${ }^{(42)}$. Previously, parents' income level has been found to be associated with misreporting of their children's food consumption, with misreporting more frequent in low- and medium-income groups than in the high-income group ${ }^{(43)}$. In addition, socio-economic status may be associated with home food availability $^{(44)}$. The present study sample was quite highly educated which might have introduced some bias in our results. Furthermore, the sample eligible for analyses was somewhat more educated than the excluded participants and there were more boys among the excluded participants. This suggests that our data were not missing at random, which might have influenced the results. However, we adjusted for the family's educational level in our models.

In the present study, we measured the home food availability with self-reported questions about the frequency of availability of fruits and vegetables as well as sugar-enriched foods. As van der Horst et al. stated, most of the studies reporting associations between the home food environment and dietary behaviours rely on selfreported data, making it hard to judge the validity and reliability of the results ${ }^{(35)}$. However, the availability scores used in the present paper had acceptable Cronbach's $\alpha$ (0.62 and 0.72$)$ suggesting at least some reliability ${ }^{(45)}$, although its validity could not be tested. In our study, the fruits and vegetables availability score was not associated with the sweets-and-treats pattern when entered in the model alone and became significant only when entered together with the sugar-enriched availability score. Such a change (increase in magnitude of the association between the independent and dependent variable after the statistical removal of a confounding effect) could indicate suppression $^{(46)}$. Hence, it may be concluded that they both are important dimensions of food availability and should be included in studies investigating food availability. Objective measurements of the home food availability would be somewhat challenging to arrange, taking account of the large and geographically diverse sample in the present study. One solution would be to use a proxy of home food availability by using purchase data from large national grocery store chains and their loyalty cards. This would also allow a wider approach when composing home food availability scores compared with our scores that were restricted to only two food categories: vegetables and fruits and sugar-enriched foods. Nevertheless, this kind of approach has its own pitfalls: it does not necessarily cover everything that is available in the home and the samples derived from customers of specific grocery store chains may be prone to selection bias.

\section{Conclusions}

In the present study, home food availability was associated with dietary patterns among Finnish children of pre-school age. In particular, the availability of sugar-enriched foods was associated with the sweets-and-treats pattern, whereas the availability of fruits and vegetables was associated with the health-conscious and vegetables-andprocessed meats patterns. These results suggest that it is important to encourage families to build healthy home food environments, and especially to limit the availability and accessibility of sugar-enriched foods in the home.

\section{Acknowledgements}

Acknowledgements: The authors thank the pre-schools, the pre-school personnel and the families for their participation in the DAGIS study and the staff for data collection. Financial support: This work is part of the DAGIS Consortium Project funded by the Academy of Finland (decision numbers 285439, 288038, 287195 and 287288), Cultural Foundation/South Ostrhobothnia Regional Fund, Folkhälsan Research Center, Juho Vainio Foundation, Päivikki and Sakari Sohlberg Foundation, Signe and Ane Gyllenberg Foundation, Finnish Foundation for Nutrition Research and Finnish Food Research Foundation, and University of Helsinki. H.V.'s work was funded by Doctoral Programme in Population Health (DocPop), University of Helsinki. The funders had no role in study design; in the collection, analysis and interpretation of the data; in the writing of the report; or in the decision to submit the article for publication. Conflict of interest: Author L.Kor. is a board member of TwoDads Ltd; the authors declare no other relationships or activities that could appear to have influenced the present work. Authorship: H.V., L.Kor., R.L., C.R., K.N., E.R. and M.E. conceived the study and/or contributed to the planning and the design of the study. H.V., L.Kor., R.L., C.R., K.N. and E.S. collected the data and/or conducted data manipulation and analyses. V.M., M.F. and M.E. contributed to the statistical analyses. H.V. wrote the manuscript. L.Kor., V.M., R.L., C.R., K.N., E.S., M.F., L.Koi., E.R. and M.E. supplied comments. All authors read and approved the final manuscript. Ethics of buman subject participation: This study was conducted according to the guidelines laid down in the Declaration of 
Helsinki and all procedures involving human subjects were approved by the University of Helsinki Review Board in the Humanities and Social and Behavioural Sciences in February 2015. A parent or legal guardian of each participant provided written informed consent.

\section{Supplementary material}

To view supplementary material for this article, please visit https://doi.org/10.1017/S1368980017003871

\section{References}

1. Ng M, Fleming T, Robinson M et al. (2014) Global, regional, and national prevalence of overweight and obesity in children and adults during 1980-2013: a systematic analysis for the Global Burden of Disease Study 2013. Lancet 384, 766-781.

2. de Onis M, Blössner M \& Borghi E (2010) Global prevalence and trends of overweight and obesity among preschool children. Am J Clin Nutr 92, 1257-1264.

3. van der Klaauw AA \& Farooqi IS (2015) The hunger genes: pathways to obesity. Cell 161, 119-132.

4. Munt AE, Partridge SR \& Allman-Farinelli M (2017) The barriers and enablers of healthy eating among young adults: a missing piece of the obesity puzzle: a scoping review. Obes Rev 18, 1-17.

5. Alexander MA \& Sherman JB (1991) Factors associated with obesity in school children. J Sch Nurs 7, 6-10.

6. Story M, Kaphingst KM, Robinson-O'Brien R et al. (2008) Creating healthy food and eating environments: policy and environmental approaches. Annu Rev Public Health 29, 253-272.

7. Townshend T \& Lake AA (2009) Obesogenic urban form: theory, policy and practice. Health Place 15, 909-916.

8. Lake A \& Townshend T (2006) Obesogenic environments: exploring the built and food environments. $J$ R Soc Promot Health 126, 262-267.

9. Cullen KW, Baranowski T, Owens E et al. (2003) Availability, accessibility, and preferences for fruit, $100 \%$ fruit juice, and vegetables influence children's dietary behavior. Health Educ Behav 30, 615-626.

10. Wyse R, Campbell E, Nathan N et al. (2011) Associations between characteristics of the home food environment and fruit and vegetable intake in preschool children: a crosssectional study. BMC Public Health 11, 938.

11. Shim JE, Kim J, Lee Y et al. (2016) Fruit and vegetable intakes of preschool children are associated with feeding practices facilitating internalization of extrinsic motivation. J Nutr Educ Behav 48, 311-317.e1.

12. Jago R, Baranowski T \& Baranowski JC (2007) Fruit and vegetable availability: a micro environmental mediating variable? Public Health Nutr 10, 681-689.

13. Pearson N, Biddle SJH \& Gorely T (2009) Family correlates of fruit and vegetable consumption in children and adolescents: a systematic review. Public Health Nutr 12, 267-283.

14. Vereecken C, Haerens L, De Bourdeaudhuij I et al. (2010) The relationship between children's home food environment and dietary patterns in childhood and adolescence. Public Health Nutr 13, 1729-1735.

15. Campbell KJ, Crawford DA, Salmon J et al. (2007) Associations between the home food environment and obesity-promoting eating behaviors in adolescence. Obesity (Silver Spring) 15, 719-730.
16. Wang L, Dalton WT, Schetzina KE et al. (2013) Home food environment, dietary intake, and weight among overweight and obese children in Southern Appalachia. South Med J 106, 550-557.

17. Tapsell LC, Neale EP, Satija A et al. (2016) Foods, nutrients, and dietary patterns: interconnections and implications for dietary guidelines. Adv Nutr 7, 445-454.

18. Willett W (2013) Issues in analysis and presentation of dietary data. In Nutritional Epidemiology, 3rd ed. pp. 305-333 [W Willett, editor]. New York: Oxford University Press.

19. Ranjit N, Wilkinson AV, Lytle LM et al. (2015) Socioeconomic inequalities in children's diet: the role of the home food environment. Int J Behav Nutr Phys Act 12, Suppl. 1, S4

20. Couch SC, Glanz K, Zhou C et al. (2014) Home food environment in relation to children's diet quality and weight status. J Acad Nutr Diet 114, 1569-1579.e1.

21. Torres R, Serrano M, Pérez CM et al. (2014) Physical environment, diet quality, and body weight in a group of 12 -year-old children from four public schools in Puerto Rico. P R Health Sci J 33, 14-21.

22. Vepsäläinen H, Mikkilä V, Erkkola M et al. (2015) Association between home and school food environments and dietary patterns among 9-11-year-old children in 12 countries. Int J Obes Suppl 5 Suppl. 2, S66-S73.

23. Østbye T, Malhotra R, Stroo M et al. (2013) The effect of the home environment on physical activity and dietary intake in preschool children. Int J Obes (Lond) 37, 1314-1321.

24. Määttä S, Lehto R, Nislin M et al. (2015) Increased health and well-being in preschools (DAGIS): rationale and design for a randomized controlled trial. BMC Public Health 15, 402.

25. Kenward MG \& Roger JH (1997) Small sample inference for fixed effects from restricted maximum likelihood. Biometrics 53, 983-997.

26. Smithers LG, Golley RK, Brazionis L et al. (2011) Characterizing whole diets of young children from developed countries and the association between diet and health: a systematic review. Nutr Rev 69, 449-467.

27. Northstone K \& Emmett P (2005) Multivariate analysis of diet in children at four and seven years of age and associations with socio-demographic characteristics. Eur J Clin Nutr 59, 751-760.

28. Nobre LN, Lamounier JA \& Franceschini SCC (2012) Preschool children dietary patterns and associated factors. J Pediatr (Rio J) 88, 129-136.

29. Lioret S, Touvier M, Lafay L et al. (2008) Dietary and physical activity patterns in French children are related to overweight and socioeconomic status. J Nutr 138, 101-107.

30. Mikkilä V, Vepsäläinen $\mathrm{H}$, Saloheimo $\mathrm{T}$ et al. (2015) An international comparison of dietary patterns in 9-11-yearold children. Int J Obes Suppl 5, Suppl. 2, S17-S21.

31. Rasmussen M, Krølner R, Klepp K-I et al. (2006) Determinants of fruit and vegetable consumption among children and adolescents: a review of the literature. Part I: quantitative studies. Int J Behav Nutr Phys Act 3, 22.

32. Campbell KJ, Crawford DA \& Hesketh KD (2007) Australian parents' views on their 5-6-year-old children's food choices. Health Promot Int 22, 11-18.

33. Calderon J, Ayala GX, Elder JP et al. (2016) What happens when parents and children go grocery shopping? An observational study of Latino dyads in Southern California, USA. Health Educ Behav 44, 5-12.

34. Calloway EE, Ranjit N, Sweitzer SJ et al. (2016) Exploratory cross-sectional study of factors associated with the healthfulness of parental responses to child food purchasing requests. Matern Child Health J 20, 1569-1577.

35. van der Horst K, Oenema A, Ferreira I et al. (2007) A systematic review of environmental correlates of obesityrelated dietary behaviors in youth. Health Educ Res 22, 203-226. 
36. Ray C, Määttä S, Roos G et al. (2016) Vanhempien käsityksiä päiväkoti-ikäisten lasten kasvisten, hedelmien ja sokeripitoisten elintarvikkeiden syömiseen vaikuttavista tekijöistä (abstract in English). J Early Child Educ Res 5, 115-135.

37. Ogden J, Reynolds R \& Smith A (2006) Expanding the concept of parental control: a role for overt and covert control in children's snacking behaviour? Appetite 47, 100-106.

38. Fisher JO \& Birch LL (1999) Restricting access to palatable foods affects children's behavioral response, food selection, and intake. Am J Clin Nutr 69, 1264-1272.

39. Rosenkranz RR \& Dzewaltowski DA (2008) Model of the home food environment pertaining to childhood obesity. Nutr Rev 66, 123-140.

40. Tilles-Tirkkonen T, Suominen S, Liukkonen J et al. (2015) Determinants of a regular intake of a nutritionally balanced school lunch among 10-17-year-old schoolchildren with special reference to sense of coherence. J Hum Nutr Diet 28, 56-63.

41. Ong JX, Ullah S, Magarey A et al. (2016) Positive influences of home food environment on primary-school children's diet and weight status: a structural equation model approach. Public Health Nutr 19, 2525-2534.

42. Markussen MS, Veierød MB, Ursin G et al. (2016) The effect of under-reporting of energy intake on dietary patterns and on the associations between dietary patterns and selfreported chronic disease in women aged 50-69 years. Br J Nutr 116, 547-558.

43. Börnhorst C, Huybrechts I, Ahrens W et al. (2013) Prevalence and determinants of misreporting among European children in proxy-reported $24 \mathrm{~h}$ dietary recalls. Br J Nutr 109, 1257-1265.

44. Zarnowiecki DM, Dollman J \& Parletta N (2014) Associations between predictors of children's dietary intake and socioeconomic position: a systematic review of the literature. Obes Rev 15, 375-391.

45. Lytle LA (2009) Measuring the food environment: state of the science. Am J Prev Med 36, Suppl. 4, S134-S144.

46. MacKinnon DP, Krull JL \& Lockwood CM (2000) Equivalence of the mediation, confounding and suppression effect. Prev Sci 1, 173. 